\title{
PROTEOMIC STUDY: LIVER METABOLISM THROUGH A COMPARISON OF THE PROTEIN EXPRESSION PROFILES OF THE TWO BREEDS - CHIANINA AND HOLSTEIN
}

\author{
Leonardo Murgiano ${ }^{1}$, Anna Maria Timperio ${ }^{2}$, Lello Zolla ${ }^{2}$, Silvia Bongiorni ${ }^{1}$, Alessio Valentini ${ }^{1}$, \\ Lorraine Pariset ${ }^{1}$ \\ ${ }^{1}$ Dipartimento di Produzioni Animali, Universita della Tuscia, Viterbo, Italy \\ ${ }^{2}$ Dipartimento di Scienze Ambientali, Universita della Tuscia, Viterbo, Italy \\ lmurgiano@unitus.it
}

\begin{abstract}
The Bos taurus breeds Holstein and Chianina are representatives of the extreme selection mainly for milk and meat traits. In the present study, we wanted to assess if selection for different purposes had effect into liver metabolism by comparing protein expression profiles of the two breeds. We applied two-dimensional polyacrylamide gel electrophoresis (2DE) to identify proteins which are differentially expressed in the two breeds. A total of $560 \pm 57$ spots were matched between the Chianina and the Holstein. Thirty nine differential expressed proteins were characterized between the two breeds. Taken together, our study performed at the proteomic level clearly supports deep changes in metabolism induced by human selection in the Holstein and the Chianina. Differential proteomic profiles of two bovine livers were established and analyzed by means of immobilized $\mathrm{pH}$ gradient-based two-dimensional polyacrylamide gel electrophoresis (2D IEF-SDS- PAGE) and electrospray/ionization time of flight mass spectrometry (qTOF-MS). For the analysis a sampling of 12 animals (six Chianina and six Holstein) was considered. For each animal the 2D electrophoresis protein extraction step was performed separately. Three technical replicates were run to reduce the technical variance for each average sample. Interestingly, most of the proteins found up-regulated as well as newly expressed (on) in the Chianina with respect to Holstein resulted involved in the anabolic pathways. On the contrary, newly expressed proteins in Holstein were related with hormone homeostasis and in thermoregulatory ability. In Holstein we found an overexpressed protein belonging to sulfotransferase (SULT1C2) family that plays a key role in biosynthesis and homeostasis of a number of hormones, including estrogens and iodothyronines.
\end{abstract}

Key words: liver proteins; proteomics; cattle breeds; 2D-IEF-SDS-PAGE; MS/MS

\section{ПРОТЕОМСКА СТУДИЈА: МЕТАБОЛИЗМОТ НА ЦРНИОТ ДРОБ ПРЕКУ СПОРЕДБА НА ПРОТЕИНСКИТЕ ПРОФИЛИ КАЈ ДВЕ РАСИ - ЧИЈАНИНА И ХОЛШТАЈН}

Говедата од расите холштајн и чијанина се претставници на екстремната селекција, и тоа претежно за млечни и месни својства. Целта на оваа студија е да се процени дали селекцијата за различни цели има влијание врз метаболизмот на црниот дроб, и тоа споредувајќи ги протеинските профили на двете раси. За идентификација на протеините кои се различно изразени кај двете раси применивме дводимензионална полиакриламидна гел-електрофореза (2DE), Вкупно беа споредени $560 \pm 57$ точки помеѓу чијанина и холштајн и беа определени триесет и девет различно изразени протеини. Нашата студија изведена на протеинско ниво јасно ги потврди длабоките промени во метаболизмот, предизвикани од хуманата селекција кај холштајн и чијанина. Различните протеински профили на црниот дроб кај двете раси говеда беа установени и анализирани со имобилизирана дводимензионална полиакриламидна гел-електрофореза, базирана на pH (2D IEF-SDS-PAGE) и електроспрејна/јонизирачка групна спектрофотометрија (q TOF-MS). За анализата беа земени примероци од 12 животни (шест чијанина и шест холштајн). Дводимензионална електрофорезна протеинска екстракција беше изведена одделно за секое животно. Беа направени три технички копии за да се редуцира техничката варијација на секој просечен примерок. Интересно е дека најголемиот дел од најдените протеини, и тоа регуларни и новоутврдени, кај чијанина, во споредба со холштајн, беа вклучени во анаболитичките патишта. Спротивно, новоутврдените протеини кај холштајн беа во релација со хормонската хомеостаза и терморегулаторната способност. Кај холштајн најдовме силно изразен протеин кој припаѓa на фамилијата сулфотрансфераза (SULT1C2) и кој игра клучна улога во биосинтезата и хомеостазата на бројни хормони, вклучувајќи ги естрогените и јодотиронините.

Клучни зборови: протеини на црн дроб; протеомиски; раси говеда; 2D-IEF-SDS-PAGE; MS/MS 


\section{INTRODUCTION}

In dairy animals in the past the primary focus of selection has been to improve milk yield, a polygenic trait for which a few potential candidate genes have been recognized. Polymorphisms of genes encoding proteins that act on metabolic pathways involved in other economically interesting traits can be of great help in defining comprehensive genetic improvement strategies. Bovine milk has a high significance in human nutrition and economy, nevertheless the characterization of the proteins composing its minor fraction is not yet complete [1]. Milk protein composition changes during lactation phases [2]. Moreover, a whole additional range of biologically active proteins and peptides have been identified in milk, some of which have antimicrobial properties [3]. Proteins associated with inflammatory reaction have also been detected in milk during infections [4].

Milk-fat globules originate as small droplets of fat near the basal region of the secretory cell. As the synthesis of triacylglycerol proceeds, they migrate through the cytoplasm, gradually increasing in size, until they reach the apical surface of the cell. The globules are secreted from the cell surrounded by a thin membrane called milk-fat-globule membrane (MFGM) [5]. The proteins constituting the MFMG are a unique and small (quantitatively speaking) subcategory of milk proteins (approximately $2-4 \%$ of the total protein in human milk), the content of which is still largely unknown $[6,7]$.

Given the nutraceutical and biological importance of these proteins, studies on MFGM formation are increasing $[2,8,9]$.

The first hypothesis about MFGM formation is that lipid droplets are gradually enveloped by the apical plasma membrane in the budding process, and therefore the MFGM is derived solely from the apical plasma membrane $[10,11]$. Alternatively, lipid secretion could result from the progressive fusion of secretory vesicles derived from Golgi that surround the lipid droplets within the cytoplasm $[12,13]$. The third view is that secretory vesicles associated with lipid droplets would fuse each other and with the apical membrane yielding a composite membrane derived from both the apical plasma membrane and the vesicles $[13,14]$.

The vectorial transport of lipid droplets from the basal region of the cell to the apical membrane for secretion is another unique feature of lipid se- cretion in mammary epithelial cells [10]. In mammary these cells most microtubules are oriented perpendicularly to the apical plasma membrane and concentrated in the medial and apical portions of the cell cytoplasm [15].

Bovine MFGM can be isolated by a simple procedure in which the fat globules are separated from the whole milk and washed several times with physiological buffers to lay down caseins. The membrane is then released from the surface of the globules by physical or chemical means and collected by centrifugation [16-20].

We focused our attention on the MFMG protein fraction because the MFG micelles contain membrane proteins of the cells of the mammary gland, and are more easily to collect than the mammary gland tissue that can be obtained only from a biopsy or sacrifying feeding cattle. The MFGM analysis could therefore turn out as an economically and ethically suitable method.

We used this strategy to investigate differences in the protein content in the milk of two cattle breeds with a different attitude (Holstein and Chianina) collected 7 days after delivery. Holstein (also known as 'Holstein Friesian' or Friesian) is today the world's highest production dairy breed.

The Chianina is one of the oldest cattle breeds, originating in the Chiana Valley in Italy. Dating back to the time of the Roman Empire, the Chianina was originally developed as a dual purpose breed for meat and draught purposes.

We present preliminary data showing differences in the protein contents between the two breeds.

\section{EXPERIMENTAL PROCEDURE}

\section{Sample collection}

Examined individuals were raised in the same farm under the same conditions. Two fresh milk samples per breed were collected and transported in ice to the laboratory.

$500 \mathrm{ml}$ of milk were centrifuged at $2000 \mathrm{~g}$ for $30 \mathrm{~min}$ at $4^{\circ} \mathrm{C}$ to remove cells to obtain cream. The recovered cream layer was washed five times with $7.4 \mathrm{pH}$ Phosphate Saline Buffer solution to remove caseins. Washed globules (WGs) were stored at $-20{ }^{\circ} \mathrm{C}$ until use. 


\section{MFGM extraction}

To extract the MFGM proteins, washed cream was mixed 1:3 with an SDS-containing solution ( $7 \mathrm{M}$ urea, $2 \mathrm{M}$ thiourea, 4\% CHAPS, 1\% Triton X-100, $20 \mathrm{mM}$ Tris, $1 \%$ DTT and $0.5 \%$ IPG buffer) as suggested by Quaranta et al. [21], incubated in ice for $60 \mathrm{~min}$ periodically vortexing, and centrifuged at 10,000 g for 1 hour. After removing the floating cream layer, the supernatant was subjected to precipitation with methanol and chloroform following Wessel et al. [22]. Before focusing, the sample was incubated in a solution of $7 \mathrm{M}$ urea, $2 \mathrm{M}$ thiourea, $4 \%$ CHAPS, $20 \mathrm{mM}$ Tris, $\mathrm{pH}$ 3-10 carrier ampholyte, $40 \mathrm{mM}$ Tris, $5 \mathrm{mM}$ TBP, 0.1 mMEDTA (pH 8.5), $2 \%(\mathrm{v} / \mathrm{v})$ protease inhibitor cocktail (Sigma-Aldrich) for $3 \mathrm{~h}$ at room temperature, under strong agitation. To prevent overalkylation, acrylamide was destroyed by adding an equimolar amount of DTE buffer which was then used as a sample solution to solubilise the precipitated proteins.

\section{Semiquantitative IEF-SDS PAGE}

IEF was performed using ready-to-use Immobiline Dry-Strips, linear pH gradient 3-10 length $18 \mathrm{~cm}$ (Biorad) and the in gel sample rehydration method. IEF was run on a Protean IEF (Biorad) at $20 \mathrm{C}$ constant temperature and $8000 \mathrm{~V}$ for 99000 Vh. After IEF the IPG gel strips were incubated at room temperature for $30 \mathrm{~min}$ in $6 \mathrm{M}$ urea, $30 \%$ w/v glycerol, $2 \% \mathrm{w} / \mathrm{v}$ SDS, $5 \mathrm{mM}$ Tris- $\mathrm{HCl}, \mathrm{pH}$ 8.6. The strips were sealed at the top of the $1.0 \mathrm{~mm}$ vertical second dimensional gels (Ettan DALT II system, Amersham Biosciences) with $0.5 \%$ agarose in $25 \mathrm{mM}$ Tris, $192 \mathrm{mM}$ glycine, $0.1 \%$ SDS, $\mathrm{pH}$ 8.3. SDS-PAGE was carried out on homogeneous running gels of $12 \% \mathrm{~T} 3 \% \mathrm{C}$. The running buffer was $25 \mathrm{mM}$ Tris, $192 \mathrm{mM}$ glycine, $0.1 \%$ SDS, $\mathrm{pH} 8.3$ and running conditions were 40 $\mathrm{mA} /$ gel until the bromophenol blue reached the bottom of the gels. The molecular weight markers used were Wide Range.

Weight Electrophoresis Calibration Kit (Amersham Biosciences). Gels were automatically stained using the Processor Plus (Amersham Biosciences) with Brilliant Blue G colloidal (Sigma, St. Louis, MO, USA) following the manufacturer's instructions.

2-DE gels were digitized at 300 dpi (ImageScanner; Amersham Biosciences). The image analysis was performed using the software ImageMaster 2D Elite V3.1 (Amersham Biosciences).

\section{Mass spectrometry}

Spots of interest were cut from the gel and destained overnight with a solution of $50 \mathrm{mM}$ ammonium bicarbonate. The proteins were in-gel digested with trypsin (Promega, Madison, WI, USA) as described by Hellmann [23].

Peptide mixtures were separated using a nanoflow-HPLC system, and subsequently eluted directly into a High Capacity ion Trap (BRAND??). Protein identification was performed by searching in the National Center for Biotechnology Information non-redundant database (NCBInr) using the Mascot program.

\section{RESULTS AND DISCUSSION}

In 2D maps differences in protein contents between the two breeds can be observed. Preliminary mass spectrometry results show the caseins amount laying down and successful extraction of MFGM proteins.

The semiquantitative analysis shows an increase of glycoprotein antigen MGP57/53 and ADRP in the Chianina in respect of Fresian milk MFGM. MGP57/53 protein, an analogue of Milk Fat Globules-EGF8, is associated with cell apoptosis and involved in mammary gland remodelling during involution. EGF8 is in fact a critical protein for the mammary gland remodelling during involution in EGF8 knockout mice. A deficiency in EGF8 causes delayed clearance of apoptotic mammary epithelial cells as well as impaired involution and inflammation of the mammary gland [24-29].

This leads to the conclusion that EGF8 could have a role in the structure of the Chianina mammary gland, smaller in size compared to the Holstein, and not specialized for large-scale milk production. Its differential expression could be a result of different selection in the two breeds.

ADRP, previously believed to be specific to adipocytes, is a major constituent of the globule surface and is present in a complex containing stoichiometric amounts of xanthine oxidase and butyrophilin. This protein might be involved in the deposition of triacylglycerols into droplets in the 
cytosol, a phenomenon known to occur both in adipocytes and in mammary epithelial cells. The results suggest a different lipid composition in the milk MFGM of the Chianina, breed whose milk is probably richer in fat.

Polymeric immunoglobulin receptor (PIGR) results overexpressed in the Holstein MFGM fraction.

PIGR, a member of the immunoglobulin superfamily, is expressed in several glandular epithelia including those of liver and mammary gland. It mediates transcellular transport of polymeric immunoglobulin molecules. Recently, $\mathrm{Ng}$ et al. [30] tested milk protein effectiveness against HIV1 proteins. It has been shown that PIGR inhibits HIV-1 protease and HIV-1 integrase, with a power similar to that of lactoferrin [30]. This suggests that the Holstein MFGM contains a larger amount of proteins with antiviral and antibacterial-activity.

\section{CONCLUSION}

MFG micelles contain membrane proteins of the mammary gland cells, more easily collectable than the lactating cows mammary gland tissue, achievable only by a biopsy or by sacrifying feeding cattle. We propose the MFGM analysis as an economically and ethically suitable method for the analysis of mammary gland proteins.

Using a proteomics approach, we have successfully identified some of the major proteins in MFGMs and mammary cytosolic lipid droplets. We utilized a nonbiased method for the discovery of specific molecules involved in a unique secretory function.

We have analysed samples of two extreme cattle breeds, and our preliminary results point out that protein differences at the MGF level can be observed. PIGR, having role in the immunoglobulin function, is overexpressed in the Holstein, which is a highly specialized dairy breed. EGF8, a protein involved in the lactation process and showing an antiviral activity, and ADRP, a protein involved in lipid deposition, is overexpressed in the Chianina beef breed.

These data provide us with a preliminary set of tools suitable to increase our knowledge of the complex mechanism involved in the secretion of lipids in the mammary epithelial cell.
Our study shows that proteomics is a suitable method for the investigation of the characteristics of the milk proteins and suggests differences in the MFGM protein expression between the Holstein and the Chianina that deserve to be further investigated.

Acknowledgments: We wish to thank Stefano Corbianco for providing the samples, doctor Maria Giulia Egidi for the help in the mass spectrometry analysis and Paolo Ciorba for the sampling assistance.

\section{REFERENCES}

[1] Smolenski, S. H., Fiona Y. S., Kwan, J. B., Farr, V., Davis, S. R., Stelwagen, K., Wheeler, T. T. (2007): Characterisation of Host Defence Proteins in Milk Using a Proteomic Approach Grant. J. Prot. Res., 6, 207-215.

[2] Reinhardt, T. A., Lippolis, J. D. (2007): Developmental Changes in the Milk Fat Globule Membrane Proteome during the Transition from Colostrum to Milk. J. Dairy Sci., 91, 2307-2318.

[3] Clare, D. A., Swaisgood, H. E. (2000): Bioactive milk peptides: A prospectus. J. Dairy Sci., 83 (6), 1187-1195.

[4] Eckersall, P. D., Young, F. J., McComb, C.; Hogarth, C. J., Safi, S., Weber, A., McDonald, T., Nolan, A. M., Fitzpatrick, J. L. (2001): Acute phase proteins in serum and milk from dairy cows with clinical mastitis, Vet. Rec. 148 (2), 35-41.

[5] Peterson, J. A., Scallan, C. D., Ceriani, R. L., Hamosh, M. (2001): Structural and functional aspects of three major glycoproteins of the human milk fat globule membrane. Adv. Exp. Med. Biol., 501, 179-187.

[6] O’Donnell, R., Holland, J.W., Deeth, H.C., Alewood, P. (2004): Milk proteomics. Int. Dairy J., 14 (12), 10131023.

[7] Wilson, N. L., Robinson, L. J., Donnet, A., Bovetto, L., Packer, N. H., Karlsson, N. G. (2008): Glycoproteomics of Milk: Differences in Sugar Epitopes on Human and Bovine Milk Fat Globule Membranes. J. Proteome Res., 7 (9), 3687-3696.

[8] Lopez, C., Briad-Bion, V., Menard, O., Russeau, F., Pradel, P., Besle, J. M. (2008): Phospholipid, Sphingolipid, and Fatty Acid Compositions of the Milk Fat Globule Membrane are Modified by Diet., J. Agric. Food Chem., 56, 5226-5236.

[9] Fong, B. Y., Norris, C. S. (2009): Quantification of Milk Fat Globule Membrane Proteins Using Selected Reaction Monitoring Mass Spectrometry. J. Agric. Food Chem., 57, 6021-6028.

[10] Mather, I. H., Keenan, T. W. (1998): Origin and secretion of milk lipids. J. Mam. Gland Biol. Neoplasia, 3, 259273.

[11] Keenan, T. W., Patton, S. (1995): Structure of milk: implications for sampling and storage, In: Jensen, R. G. (Ed.), Handbook of Milk Composition, Academic Press, San Diego, CA, pp. 5-49.. 
[12] Wooding, F. B. (1973): Formation of the milk fat globule membrane without participation of the plasmalemma. $J$. Cell Sci., 13, 221-235.

[13] Wooding, F. B. (1971): The mechanism of secretion of the milk fat globule J. Cell Sci. 9, 805-821.

[14] Kralj, M., Pipan, N., Methka, K., Nada, P. (1992): The role of exocytosis in the apocrine secretion of milk lipid globules in mouse mammary gland during lactogenesis. Biol. Cell, 76, 288-293.

[15] Nickerson, S. C., Keenan, T. W. (1979): Distribution and orientation of microtubules in milk secreting epithelial cells of rat mammary gland Cell Tissue Res., 202, 303312.

[16] McPherson, A. V., B. J. Kitchen (1983): Reviews of the progress dairy science: the bovine milk fat globule membrane - its formation, composition, structure and behaviour in milk and dairy products. J. Dairy Res., 50, 107133.

[17] Mather, I. H. (1987): Proteins of the milk-fat-globule membrane as markers of mammary epithelial cells and apical plasmamembrane, In: The Mammary Gland: Development, Regulation and Function. M. C. Neville and C. W. Daniel, eds., Plenum Publ. Corp., New York, NY pp. 217-267.

[18] Keenan, T. W., I. H. Mather, and D. P. Dylewski (1988): Physical equilibria: lipid phase. In: Fundamentals of Dairy Chemistry. 3rd ed. N. P. Wong, ed. Van Nostrand Reinhold Co., New York, NY, pp 511-582.

[19] Mather, I. H. (2000): A Review and Proposed Nomenclature for Major Proteins of the Milk-Fat Globule Membrane. J Dairy Sci., 83, 203-247.

[20] Keenan, T. W., Patton, S. (1995): The structure of milk: Implications for sampling and storage. The milk lipid globule membrane. In: A Handbook of Milk Composition. R. G. Jensen, ed. Academic Press, Inc., New York, NY, pp 5-50.

[21] Quaranta, S., Giuffrida, M. G., Cavaletto, M., Giunta, C., Godovac-Zimmermann, J., Canas, B., Fabris, C., Bertino, E., Mombro, M., Conti. A. (2001): Human proteome enhancement: High-recovery method and improved twodimensional map of colostral fat globule membrane proteins. Electrophoresis, 22, 1810-1818.
[22] Wessel, D., Flugge, U. I. (1984): A method for the quantitative recovery of protein in dilute solution in the presence of detergents and lipids. Anal Biochem., 138 (1), 141-143.

[23] Hellmann, U., Wernstedt, C., Gonez, J., Heldin, C. H. (1995): Improvement of an "In-Gel" digestion procedure for the micropreparation of internal protein fragments for amino acid sequencing. Anal. Biochem., 224, 451-455.

[24] Cover, T. L., Blaser, M. J. (1992): Helicobacter pylori and gastroduodenal disease., Annu. Rev. Med., 43, 135145 .

[25] Ernst, P. (1999): The role of inflammation in the pathogenesis of gastric cancer. Aliment. Pharmacol. Ther., 13 (Suppl. 1), 13-18.

[26] Stefferl, A., Schubari, A., Storch, M., Amini, A., Mather, I., Lassm, H., Linington. C. (2000): Butyrophilin, a milk protein, modulates the encephalitogenic $\mathrm{T}$ cell response to myelin oligoddendrocyte glycoprotein in experimental autoimmune encephalomyelitis. J. Immunol., 165, 28592865.

[27] Guggenmos, J. A., Schubari, S., Ogg, S., Anderson, M., Olsson, T., Mather, I. H., Linington, C. (2004): Antibody cross-reactivity between myelin oligodendrocyte glycoprotein and the milk butyrophilin in multiple sclerosis. $J$. Immunol., 172, 661-668.

[28] Mana, P., Goodyear, M., Bernard, C., Tomioka, R., Freire-Garabal, M., Linares, D. (2004): Tolerance induction by molecular mimicry: Prevention and suppression of experimental autoimmune encephalomyelitis with the milk protein butyrophilin. Int. Immunol., 16 (3), 489499.

[29] Keenan, T. W., Powell, E. M., Sasaki, M., Eigle, W. N., Franke. W. W. (1977): Membranes of mammary gland. XIV. Isolation and partial characterization of a high molecular weight glycoprotein fraction from bovine milk fat globule membrane. Cytobiologie, 15, 96-115.

[30] Ng, T. B., Lam, T. L., Au, T. K., Ye, X. Y., Wan, C. C. (2001): Inhibition of human immunodeficiency virus type 1 reverse transcriptase, protease and integrase by bovine milk proteins. Life Sciences, 69, 2217-2223. 
